Błachucki M., Rozwój historyczny i cele prawa konkurencji, „Ekonomia i Prawo”, Polszakiewicz B., Boehlke J. (red.), Tom XII, nr 2/2013, ss. 193-205. DOI: http://dx.doi.org/10.12775/ $\underline{\text { EiP.2013.015 }}$

\author{
MATEUSZ BŁACHUCKI*
}

\title{
ROZWÓJ HISTORYCZNY I CELE PRAWA KONKURENCJI
}

\section{STRESZCZENIE}

Artykuł analizuje rozwój historyczny prawa konkurencji, pokazując powody przyświecające ustawodawcom przy uchwalaniu ustaw antymonopolowych. Następująca potem analiza poszczególnych celów prawa konkurencji pokazuje, że brak jest pełnej zgody co do celów prawa konkurencji. Co więcej, cele te mogą pozostawać wzajemnie sprzeczne. Stosunkowo największa liczba krajowych aktów prawnych i literatury przedmiotu opowiada się za akceptacją celu ekonomicznie uzasadnionego, tj. dobrobytu konsumenckiego. Pozostałe cele prawa konkurencji uwarunkowane są wyborami politycznymi.

Słowa kluczowe: prawo konkurencji, historia prawa, aksjologia prawa

Klasyfikacja JEL: K21, B20

\section{DEVELOPMENT AND GOALS OF COMPETITION LAW}

\author{
SUMMARY
}

The article presents the historical development of competition law discussing reasons for adopting particular national antimonopoly legislation. The following analysis of

\footnotetext{
* Mateusz Błachucki, Instytut Nauk Prawnych Polskiej Akademii Nauk, Zakład Prawa Administracyjnego, tel.: +48 503745 096, e-mail: mateusz.blachucki@inp.pan.pl.
} 
goals of competition law leads to the conclusion that there is no agreement what goals competition law should have. Furthermore some of identified goals of competition law are conflicting. Nonetheless the majority of national competition laws and the academics accept that competition law should aim at achieving the basic economic goals that is consumer welfare. The rest of possible goals of competition law depend on political choices of governments.

Keywords: competition law, history of law, axiology of law

JEL Classification: K21, B20

\section{WSTĘP}

Polityka konkurencji odgrywa istotną rolę w polityce gospodarczej współczesnych państw. Podstawowym narzędziem tej polityki jest prawo konkurencji, które stanowi istotną gwarancję efektywności prowadzonej polityki konkurencji ${ }^{1}$. Jednakże zarówno polityka konkurencji, jak i prawo konkurencji zmieniały się na przestrzeni ostatniego stulecia. Ewolucja ta pokazuje, jak długą drogę odbyło prawo konkurencji, aby osiągnąć swój współczesny kształt. Widoczne jest to szczególnie, gdy analizuje się cele tego ustawodawstwa. Często bowiem pierwotne założenia przyjmowanych ustaw były potem modyfikowane, albo też dopisywano nowe cele do już istniejących praw. $\mathrm{Za}$ mierzeniem artykułu jest zwięzłe pokazanie najistotniejszych momentów w rozwoju prawa konkurencji w celu lepszej identyfikacji celów tego prawa. Ta historyczna część zostanie uzupełniona współczesnymi poglądami nauki prawa antymonopolowego na cele prawa konkurencji.

Analiza poglądów doktryny prawa konkurencji wskazuje na wiele możliwych celów istnienia prawa antymonopolowego. Przez cel prawa należy rozumieć pewien stan rzeczy, który chce osiągnąć ustawodawca, uchwalając dane przepisy ${ }^{2}$. Należy zastrzec od razu na początku, że ustalenie celów prawa ma charakter idealistyczny i abstrahuje od tego, czy zamierzenia te rzeczywiście pojawiły się w świadomości „prawodawcy”. $\mathrm{Z}$ tego powodu w tym kontekście mówi się o celu konkretnej ustawy czy przepisów. Tutaj należy szukać wytłumaczenia dla zjawiska, że często na gruncie nauki prawa brak jest zgody co do wyczerpującego i ujednoliconego katalogu jego celów, szczególnie że niektóre z celów wymienianych przez różnych autorów są ze sobą wzajemnie sprzeczne. Taka sytuacja zachodzi także w przypadku prawa antymonopolowego.

1 A.E. Rodriguez, A. Menon, The limits fo competition policy, Wolters Kluwer, Hague, 2010, s. 93.

2 Z. Ziembiński, Wstęp do aksjologii dla prawników, Wydawnictwo Prawnicze, Warszawa 1990, s. 76.

${ }^{3}$ Ibidem, s. 77. 


\section{POJĘCIE PRAWA KONKURENCJI}

Pojęcie prawa konkurencji może być przedmiotem wielu interpretacji. Dodatkowo warto wskazać także na potencjalne konfuzje wynikające $\mathrm{z}$ porównania $z$ pokrewnym znaczeniowo pojęciem prawa antymonopolowego ${ }^{4}$. W literaturze przedmiotu wskazuje się, że prawo konkurencji to zespół norm prawnych służących rozwojowi i ochronie wolnej konkurencji przed jej ograniczeniami, mającymi swoje źródło głównie w zachowaniach przedsiębiorstw i ich związków. Wyznacza ono publicznoprawne granice swobody działalności gospodarczej i swobody umów w celu kreowania lub zachowania nieskrępowanego dokonywania wyborów gospodarczych na rynku przez jego uczestników ${ }^{5}$. W świetle innej definicji to zespół norm prawnych regulujących zasady uzyskiwania oraz wykorzystywania siły rynkowej przez przedsiębiorstwa ${ }^{6}$. Wydaje się jednak, że ta definicja jest zbyt szeroka. Bardziej operatywnym wydaje się ujmowanie prawa antymonopolowego jako zespołu norm prawa publicznego zapobiegających zachowaniu przedsiębiorców zmierzających do wyeliminowania konkurencji i ustanowieniu w zamian prywatnego monopolu.

\section{ROZWÓJ USTAWODAWSTWA ANTYMONOPOLOWEGO}

Genezy prawa konkurencji można poszukiwać już w starożytności ${ }^{8}$. Jednakże rozwój tego prawa, w kształcie, w jakim znamy je obecnie, związany jest z uchwaleniem 2 lipca 1890 r. w USA pierwszej ustawy antymonopolowej, tj. Sherman $A c t^{9}$. Amerykańskie prawo antytrustowe odgrywało przez cały okres swojego istnienia wiodącą rolę w przemianach tej gałęzi prawa na całym

${ }^{4}$ Zwraca na to uwage D.J. Gerber, Law and Competition in the Twentieth Century Europe. Protecting Prometheus, Oxford University Press, Oxford 2001, s. 4, czy S. Gronowski, Polskie prawo antymonopolowe (zarys wyktadu), Wydawnictwo ZPP, Warszawa 1998, s. 46.

5 T. Skoczny, Wprowadzenie, [w:] Prawo konkurencji, C.H. Beck, Warszawa 1995, s. X.

${ }^{6}$ D. Miąsik, Prawo konkurencji, [w:] R. Skubisz, E. Skrzydło-Tefelska (red.), Prawo europejskie. Zarys wyktadu, UMCS, Lublin 2004, s. 331.

7 L. Pace, European Antitrust Law, Edward Elgar Publishing, Cheltenham - Northampton 2007, s. 35.

8 Tak R. Molski, Prawo antymonopolowe w obliczu globalizacji, Branta, Bydgoszcz - Szczecin 2007, s. 26 i 27.

9 Ustawa ta została następnie uzupełniona przez Clayton Act (1914), Federal Trade Commission Act (1914), Robinson - Patman Act (1936), Celler - Kafauver Act (1950) oraz Hart-ScottRodino Antitrust Improvements Act (1976). 
świecie. W XIX w. i na początku XX w. formowanie się karteli i trustów było uznawane za przejaw swobody kontraktowej pozostającej w zgodzie z zasadami wolnego rynku. Dopiero uchwalenie ww. amerykańskiej ustawy stanowiło pewien przełom w myśleniu o antykonkurencyjnych porozumieniach. Uznaje się, że ustawa ta była odpowiedzią na wysoki stopień kartelizacji gospodarki amerykańskiej ${ }^{10}$ oraz tworzenie olbrzymich korporacji ${ }^{11}$. Istotnym rysem amerykańskiego prawa antytrustowego była duża ogólnikowość aktów prawnych, a główny ciężar rozwoju wzięło na siebie orzecznictwo sądowe. Amerykański system ochrony konkurencji jest bowiem systemem sądowym ${ }^{12}$.

W doktrynie amerykańskiej myślenie o prawie antymonopolowym i jego celach zostało zdominowane przez dwie szkoły, związane $z$ uniwersytetami, z których wywodzili się ich główni orędownicy, tj. Harvard i Chicago. Podstawowym założeniem szkoły harvardzkiej jest Paradygmat $\mathrm{S}_{»} \mathrm{C} \mathrm{P}$ (ang. Structure»Conduct»Performance). Zgodnie z nim struktura rynku (S) determinuje zachowanie przedsiębiorcy (C), co przekłada się na skutki rynkowe $(\mathrm{P})$. Zgodnie $\mathrm{z}$ tym założeniem istnienie pewnych struktur rynkowych będzie prowadziło do bardzo miernych skutków rynkowych ${ }^{13}$. $Z$ tego powodu polityka antymonopolowa winna być bardzo aktywna i oparta na działaniu strukturalnym. Za ostateczny cel prawa konkurencji uznawany jest na gruncie tych poglądów dobrobyt konsumentów, choć poszczególni przedstawiciele tego kierunku wskazują na możliwość realizacji także innych celów przez prawo konkurencji. Szkoła chicagowska odrzuca założenie, że struktura rynku determinuje wynik gry rynkowej. Odwołując się do założeń neoklasycznej szkoły ekonomii, wskazywano, że to nie struktura rynku, ale efektywność alokacyjna, która zapewnia najbardziej sprawiedliwy podział dóbr w społeczeństwie, powinna być jedynym celem polityki antymonopolowej ${ }^{14}$. Zwolennicy tej szkoły wierzą, że wolny rynek posiada najlepsze mechanizmy korekcyjne, polityka zaś antymonopolowa winna być bardzo ostrożna i bazować na środkach behawioralnych. Za cel prawa konkurencji uważa się ochronę dobrobytu ogólnego. Szkoła ta nie koncentruje się zatem jedynie na dobrobycie konsumenckim, ale

${ }^{10} \mathrm{Na}$ temat trustów w Ameryce w okresie uchwalania Sherman Act zob. P. Lafargue, Trusty amerykańskie. Ich dziatalność ekonomiczna, spoteczna i polityczna, Nakładem Wincentego Raabego, Warszawa 1907, s. 3 i n.

${ }_{11}$ W. F. Shughart II, Antitrust policy and interest-group politics, Quorum Books, New YorkWestport-Connecticut-London 1990, s. 11-22.

${ }_{12}$ D. J. Gerber, op. cit., s. 422.

${ }^{13}$ M. Waterson, Economic theory of the industry, Cambridge University Press, Cambridge 1988, s. 3 i n.

${ }^{14} \mathrm{G}$. Amato, Antitrust and the bounds of power. The dilemma of liberal democracy in the history of the market, Hart, Oxford 1997, s. 21 i n. 
nakazuje całościową analizę potencjalnych skutków zachowań przedsiębiorców. $\mathrm{Z}$ czasem analizy ekonomiczne zostały rozwinięte, a prawo antymonopolowe stało się przedmiotem zainteresowania innych kierunków w ekonomii, takich jak teoria gier ${ }^{15}$, teoria rynków kontestowalnych ${ }^{16}$ czy teoria Organizacji Przemysłowej (ang. Industrial Organization $)^{17}$. Jak widać, charakterystyczną cechą amerykańskiego prawa antymonopolowego jest ekonomiczna analiza skutków negatywnych zachowań przedsiębiorców. $Z$ czasem podobne podejście zyskało popularność również w Europie.

Oprócz amerykańskiej tradycji, która niewątpliwie wciąż oddziałuje na wiele państw, należy wspomnieć o europejskich i unijnych korzeniach współczesnego prawa antymonopolowego. Początków europejskiej tradycji prawa antymonopolowego upatruje się $\mathrm{w}$ pierwszych projektach ustaw antykartelowych przygotowanych u schyłku monarchii austriackiej pod koniec XIX w. Jednakże nie stały się one nigdy obowiązującym prawem ${ }^{18}$. Pierwsza ustawa dotycząca karteli został uchwalona w Niemczech w 1923 r. i była odpowiedzią na negatywny wpływ karteli na gospodarkę, co było szczególnie dotkliwe w okresie powojennego kryzysu gospodarczego oraz galopującej inflacji ${ }^{19}$. Ustawa niemiecka nie zakazywała istnienia karteli, ale próbowała je „cywilizować”. Pomimo tego, że okazała się mało skutecznym aktem, stała się wzorem dla innych państw europejskich, które uchwaliły prawa kartelowe, tj. Czechosłowacja (1930), Polska (1933), Jugosławia (1934) oraz Dania (1937). Zmiana podejścia do karteli dokonała się po zakończeniu II wojny światowej. W szczególności na uwagę zasługuje rozwój unijnego prawa konkurencji, gdyż to ono miało najistotniejsze znaczenie dla oblicza współczesnego prawa konkurencji w Europie.

Prawo konkurencji stało się jednym $\mathrm{z}$ najważniejszych filarów unijnego prawa gospodarczego dzięki zamieszczeniu przepisów je regulujących w Traktacie o Europejskiej Wspólnocie Węgla i Stali oraz w Traktacie Rzymskim ${ }^{20}$. Przepisy te okazały się bardzo istotne $\mathrm{z}$ dwóch powodów: politycznego - zapewniały osiągnięcie integracji ekonomicznej, będącej wstępem do integracji

15 L. Phlips, Competition policy: a game-theoretic perspective, Cambridge University Press, Cambridge 1995 .

${ }_{16}$ W.J. Baumol, J.C. Panzer, R.D. Willig, Contestable Markets and the Theory of Industry Structure. Revised Edition, Hartcourt Brace Jovanovich, Santiego-Toronto 1988.

17 D. Brito, M. Catalao-Lopes, Mergers and Acquisitions: The Industrial Organization Perspective, Kluwer Law International, The Hague 2006, s. 13 i n.

${ }^{18}$ D.J. Gerber, op. cit., s. 7.

19 Ibidem, s. 125.

20 Traktat ustanawiajacy Wspólnotę Europejskq (wersja skonsolidowana), Dziennik Urzędowy C 321E z 29.12.2006 r., s. 37 i n. 
politycznej oraz gospodarczego - gwarantowały wzrost dobrobytu europejskich konsumentów poprzez znoszenie barier, zapewniając tym samym istnienie wolnej gry sił rynkowych. Podstawowe przepisy zawarte zostały w art. 101 (d. art. 81), art. 102 (d. art. 82) oraz art. 106 (d. art. 86) TFUE ${ }^{21}$. Art. 101 TFUE wprowadził zakaz antykonkurencyjnych porozumień, art. 102 TFUE zabronił nadużywania pozycji dominującej przez przedsiębiorców posiadających taką silę rynkową, a art. 106 TFUE ograniczał działalność monopoli państwowych. Bardzo ważną rolę odegrało Rozporządzenie 17/6222, które stworzyło instytucjonalne oraz proceduralne ramy unijnej polityki konkurencji. Obecnie podobną rolę pełni Rozporządzenie 1/2003. Natomiast pierwszym unijnym aktem prawnym wyłącznie $z$ zakresu kontroli koncentracji było Rozporządzenie 4064/8923 zastąpione przez obecnie obowiązujące Rozporządzenie $139 / 2004^{24}$. Analiza unijnego prawa konkurencji pokazuje, że prawo to może w równym stopniu realizować cele ekonomiczne, tj. przeciwdziałać ograniczeniom konkurencji w celu ochrony interesu konsumentów, oraz cele polityczne, tj. tworzenia jednolitego rynku wewnętrznego i zniesienie barier krajowych.

\section{CELE PRAWA KONKURENCJI}

Przedstawiony zarys rozwoju prawa konkurencji pokazuje, że prawo konkurencji może służyć realizacji wielu różnych celów. Brak jest w tym względzie powszechnej zgody. Rozbieżności poglądów uzasadnione są często wyznawanymi poglądami poszczególnych autorów na zasadność i intensywność obecności państwa w gospodarce. Ponadto ustawodawca nie zawsze w sposób jasny wskazuje na swoje motywy i cele, które towarzyszą mu w trakcie uchwalania danej ustawy antymonopolowej. Powoduje to, że z biegiem czasu przepisy zaczynają funkcjonować niezależnie od woli ustawodawcy i podatne są na różne interpretacje.

Cele prawa konkurencji mogą mieć uzasadnienie ekonomiczne lub wypływać z założeń politycznych. Obecnie mamy do czynienia z ekonomiza-

${ }^{21}$ Traktat o funkcjonowaniu Unii Europejskiej (wersja skonsolidowana), Dz. U. WE C 115 z 9 maja 2008 r., s. 47 i n.

${ }^{22}$ Rozporzadzenie Rady nr 1/2003 z dnia 16 grudnia 2002 r. w sprawie wprowadzenia w $\dot{z} y-$ cie regut konkurencji ustanowionych w art. 81 i 82 Traktatu, Dz. U. UE L 001, 04/01/2003.

${ }^{23}$ Rozporzadzenie Rady 4064/89 z dnia 21 grudnia 1989 r., w sprawie kontroli koncentracji pomiędzy przedsiębiorcami, Dz. U. UE z 1990 r. L, nr 257, s. 13 i n.

${ }^{24}$ Rozporzadzenie Rady Nr 139/2004 z dnia 20 stycznia 2004 r. w sprawie kontroli koncentracji przedsiębiorstw, Dz. U. L 24, z 29.01.2004, s. 1-22. 
cją prawa konkurencji i stopniową eliminacją celów politycznych ${ }^{25}$. W doktrynie przyjmuje się, że podstawowe trzy grupy celów prawa konkurencji to: 1) zwiększenie dobrobytu konsumenckiego (lub ogólnego) poprzez stymulowanie efektywności alokacyjnej lub produkcyjnej, 2) przeciwdziałanie gromadzeniu i nadużywaniu siły rynkowej w celu ochrony wolności indywidualnej oraz praw indywidualnych, a także wolności gospodarczej w ramach konkurencji rynkowej, 3) inne szersze cele realizujące interes publiczny ${ }^{26}$.

\subsection{DOBROBYT}

W literaturze przedmiotu celem prawa antymonopolowego, który jest wskazany najczęściej jest dobrobyt. Dobrobyt może występować w dwóch formach: jako dobrobyt ogólny lub społeczny (ang. total/social welfare) lub jako dobrobyt konsumentów (ang. consumer welfare). Kryterium dobrobytu używane jest w ekonomii do oceny wydajności i skuteczności przedsiębiorstw ${ }^{27}$. Ogólny dobrobyt jest miarą łącznego dobrobytu (lub nadwyżek/zapasów) producentów i konsumentów. Nadwyżką indywidualnego producenta jest zysk, jaki osiąga ze sprzedaży danego dobra, a nadwyżką (dobrobytem) indywidualnego konsumenta jest różnica pomiędzy subiektywnym przekonaniem o wartości danej rzeczy i ceną, jaką w rzeczywistości musi on za nią zapłacić. Przyrost dobrobytu następuje, jeżeli którakolwiek z nadwyżek się powiększa. Większość ekonomistów skupia się przede wszystkim na tej formie dobrobytu, nie dokonując wartościowań pomiędzy nadwyżkami producentów oraz nadwyżkami konsumentów ${ }^{28}$.

Bardzo zbliżonym, do wspomnianego wcześniej kryterium, jest dobrobyt konsumentów. Jak wskazano wcześniej, dobrobytem indywidualnego konsumenta jest różnica pomiędzy subiektywnym przekonaniem o wartości danej rzeczy i ceną, jaką w rzeczywistości musi on za nią zapłacić. Dobrobyt konsumenta jest więc miarą nadwyżki konsumenta ${ }^{29}$. Podkreśla się, że mimo ekonomizacji prawa konkurencji to dobrobyt konsumenta, a nie efektywność alokacyjna winna być rzeczywistym celem ustawodawstwa antymonopolowe-

${ }^{25} \mathrm{Ch}$. Decker, Economics and the enforcement of European competition law, Edward Elgar, Cheltenham 2009, s. 182 i n.

${ }_{26}$ W. Sauter, Competition law and industrial Policy in the EU, Clarendon Press, Oxford 2003, s. 117.

${ }_{27}$ M. Motta, Competition Policy. Theory and Practice, Cambridge University Press, Cambridge 2007, s. 18.

28 S. Bishop, M. Walker, The Economics of EC Competition Law: Concepts, Application and Measurement, Sweet \& Maxwell, London 2002, s. 24.

${ }^{29}$ M. Motta, op. cit., s. 18 i 19. 
go $^{30}$. W przypadku unijnego prawa konkurencji, pomimo wcześniejszej niejednoznaczności, obecnie przyjmuje się, że dobrobyt konsumenta jest podstawowym celem ${ }^{31}$. Przyjęcie jako standardu dobrobytu konsumenta, a nie dobrobytu ogólnego zasadniczo nie wpływa na praktyczne stosowanie reguł prawa antymonopolowego, gdyż wynik sprawy będzie zasadniczo identyczny w przypadku obydwu rodzajów koncepcji dobrobytu ${ }^{32}$. Jednakże pewne różnice, w sytuacjach skrajnych dość istotne, mogą pojawić się w przypadku stosowania testu oceny koncentracji $\mathrm{w}$ systemie kontroli łączenia przedsiębiorców. Przyjęcie koncepcji dobrobytu konsumenta skutkuje tym, że akceptacja ewentualnych wydajności, które niesie ze sobą koncentracja, jako równoważnika dla strat konsumentów, wydaje się ograniczona ${ }^{33}$.

\subsection{WOLNOŚĆ GOSPODARCZA}

Przez wiele lat unijne prawo konkurencji rozwijało się pod przemożnym wpływem szkoły fryburskiej. Zgodnie z jej założeniami mechanizm wolnego rynku jest niezbędnym składnikiem liberalnej demokracji, jednakże nie jest on wystarczającym czynnikiem zachowania ładu gospodarczego. Konsekwencją tych założeń, były decyzje, gdzie Komisja chroniła przede wszystkim konkurentów, a nie mechanizm konkurencji jako taki ${ }^{34} . Z$ tego punktu widzenia to istnienie konkurentów gwarantuje efektywność funkcjonowania konkurentów i z tego powodu ochrona konkurentów utożsamiana jest często $\mathrm{z}$ ochroną konkurencji. Podobne uzasadnienie spotykano w zakresie poparcia tezy, że celem prawa konkurencji jest obrona mniejszych przedsiębiorców. Obrona małych i średnich przedsiębiorców jest historycznie jednym z najstarszych celów prawa antymonopolowego ${ }^{35}$. Nawet obecnie na gruncie niektórych ustawodawstw, np. niemieckiego prawa antykartelowego, możemy się spotkać z sytuacją istnienia specjalnych reguł konkurencji dla małych i średnich przedsiębiorców. „Specjalność” tych reguł sprowadza się do tego, że małe i średnie

${ }^{30}$ J.B. Kirkwood, R.H. Lande, The Fundamental Goal of Antitrust: Protecting Consumers, Not Increasing Efficiency, http://ssrn.com/abstract=1113927 (08.03.13).

31 Zob. wystapienie Nelly Kroes, Consumers at the heart of EU Competition Policy, http://europa.eu/rapid/pressReleasesAction.do?reference=SPEECH/08/212\&format=HTML\&aged=0\& language $=\mathrm{EN} \&$ guiLanguage $=$ en (08.03.13)

${ }^{32}$ S. Bishop, M. Walker, op. cit., s. 27.

${ }_{33}$ R. van den Bergh, P. Camesasca, European Competition Law and Economics. A Comparative Perspective, Sweet\&Maxwell, London 2006, s. 41 i 42.

${ }^{34}$ R. Whish, Competition Law, Oxford University Press, Oxford, 2009, s. 21.

35 W. F. Shughart II, op. cit., s. 14. 
przedsiębiorstwa wyłączone są spod niektórych zakazów antymonopolowych, np. mogą zawierać umowy przypominające porozumienia kartelowe.

Szkoła ordoliberalna, a za nią wielu ustawodawców, upatruje celu prawa konkurencji w umacnianiu wolności gospodarczej przedsiębiorców, przez zakazanie zawierania porozumień zmierzających do ograniczenia ich swobody gospodarczej i umożliwienie każdemu swobody w zakresie konkurowania $\mathrm{z}$ innymi przedsiębiorcami. Podkreśla się, że wolność gospodarcza i „prawo do konkurowania" mają silne osadzenie konstytucyjne. Ordoliberalizm postrzega zbytnią ekonomizację prawa konkurencji jako prowadzącą do niepewności prawnej i sceptycznie podchodzi do możliwości poprawnego przewidywania zdarzeń gospodarczych przy użyciu narzędzi ekonomicznych. $Z$ tego powodu prawo antymonopolowe powinno skupić się na celu możliwym do osiągnięcia i weryfikowalnym empirycznie, czyli zapewnieniu wolności gospodarczej i swobody konkurowania ${ }^{36}$. Prawo konkurencji zapewnia wolność gospodarczą także przez to, że nie dopuszcza do koncentracji siły rynkowej w jednym ręku, gdyż ta często przekłada się na siłę polityczną, co może zaburzać mechanizm demokracji. Ponadto uniemożliwienie zbytniej koncentracji gospodarczej pozwala na bardziej sprawiedliwą i rozłożoną na wiele podmiotów dystrybucję dobrobytu.

\subsection{INNE CELE REALIZUJĄCE INTERES PUBLICZNY}

Na prawo konkurencji wpływają także inne cele, które mogą powodować okresową lub trwałą modyfikację „tradycyjnych” celów prawa konkurencji. Wynika to $\mathrm{z}$ faktu, że prawo i polityka konkurencji nie istnieje w próżni i wpływa na inne polityki publiczne, tj. przemysłowa, regionalna, społeczna czy ochrony środowiska ${ }^{37}$. Przykładowo specyficznym celem unijnego prawa konkurencji jest zniesienie krajowych barier oraz umocnienie wspólnego rynku. Istnienie wspólnego rynku to jedna podstaw funkcjonowania Unii Europejskiej. Integracja rynków krajowych i znoszenie barier narodowych było od początku jednym $\mathrm{z}$ podstawowych celów unijnej polityki konkurencji ${ }^{38}$. Niewątpliwie cel ten ma charakter wybitnie polityczny, a nie gospodarczy ${ }^{39}$. Niektórzy zresztą

${ }^{36} \mathrm{R}$. Zaech, Competition law should promote economic and social welfare by ensuring the freedom to compete - a lawyer's view, [w:], J. Drexl, L. Idot, J. Moneger (red.), Economic Theory and Competition Law, Edward Elgar, Cheltenham-Northampton 2009, s.124 i 125.

37 R. van den Bergh, P. Camesasca, op. cit., s. 49.

${ }^{38}$ Bellamy \& Child, European Community law of competition, Oxford University Press, Oxford 2008, s. 40.

39 Świadczyć o tym może dodatkowo fakt, że nawet państwa o federacyjnej strukturze, jak Niemcy czy USA, nie umieszczają podobnych przepisów w swoich ustawodawstwach antymonopolowych. 
określają realizację tego celu mianem „obsesji” ${ }^{40}$, która powoduje, że zachowania firm niemające żadnych antykonkurencyjnych celów lub skutkówsą penalizowane przez unijne prawo konkurencji.

W przypadku kontroli koncentracji czy też umów kooperacyjnych prawo antymonopolowe może służyć osiąganiu określonych celów społecznych, tj. walki z bezrobociem ${ }^{41}$ czy celów z zakresu polityki regionalnej ${ }^{42}$. Prawo konkurencji może służyć w osiągnięciu określonych celów czysto politycznych. Przykładowo w powojennych Niemczech realizowano hasło „3 3 de” - demokratyzacja, denazyfikacja oraz dekartelizacja”. W tym kontekście prawo antymonopolowe miało służyć jako instrument rozbicia niemieckich struktur gospodarczych, które uważane były za jeden z głównych filarów III Rzeszy ${ }^{43}$.

\subsection{CELE POLSKIEJ USTAWY ANTYMONOPOLOWEJ}

Analizując polską ustawę antymonopolową oraz orzecznictwo sądowe i administracyjne, jakie na jej kanwie powstało, trudno dopatrzeć się koherentnej wizji celów, które ma realizować ustawa antymonopolowa. Niektórzy określają tę sytuację mianem „kontrolowanego chaosu” ${ }^{44}$. Z doktryny można wnosić, że celem polskiej ustawy jest ochrona mechanizmu konkurencji jako instrumentu służącego podnoszeniu efektywności działania oraz ochrona konsumentów przed eksploatacją ze strony silniejszych uczestników rynku ${ }^{45}$. Podnosi się także, że celów ustawy antymonopolowej jest wiele, tj. ochrona przed zachwianiem konkurencyjnej struktury rynku, ochrona małych i średnich przedsiębiorców, niedopuszczenie do eksploatacji ekonomicznie słabszych uczestników rynku, sprawiedliwa redystrybucja dochodów ${ }^{46}$.

Oprócz tego polska ustawa antymonopolowa realizuje także pozaekonomiczne cele. Jest to wynikiem oparcia ustroju gospodarczego Polski na koncepcji społecznej gospodarki rynkowej, co determinuje zachowanie ustawodawcy, który nie może zawęzić celów ustawodawstwa gospodarczego wy-

${ }^{40}$ R. Whish, op. cit., s. 23.

${ }^{41}$ A. Perrot, Appropriation of the legal system by economic concepts: should conflicting goals be considered?, [w:], J. Drexl, L. Idot, J. Moneger (red.), Economic Theory and Competition Law, Edward Elgar, Cheltenham-Northampton 2009, s. 131 i 132.

${ }^{42}$ R. Whish, op. cit., s. 22.

${ }^{43}$ M. Motta, op. cit., s. 27.

${ }^{44}$ D. Miąsik, Controlled Chaos with Consumer Welfare as the Winner - a Study of the Goals of Polish Antirust Law, „Yearbook of Antitrust and Regulatory Studies”, 2008, vol. 1(1), s. 33.

${ }^{45}$ D. Miąsik, Reguta rozsq̨dku w prawie antymonopolowym. Studium prawnoporównawcze, Zakamycze, Kraków 2004, s. 431.

${ }^{46}$ Z. Jurczyk, Cele polityki antymonopolowej w teorii i praktyce, [w:] C. Banasiński, E Stawicki (red.), Konkurencja w gospodarce wspótczesnej, UOKiK, Warszawa 2007, s. 36. 
łącznie do celów ekonomicznych, ale musi uwzględniać kontekst społeczny. Najlepszym przykładem tej obserwacji, z zakresu kontroli łączenia przedsiębiorców, jest instytucja zgody nadzwyczajnej, kiedy organ antymonopolowy autoryzuje antykonkurencyjne koncentracje przedsiębiorców, uzasadniając to ważniejszym interesem publicznym, np. bezpieczeństwem socjalnym obywateli, bezpieczeństwem narodowym czy koniecznością rozwoju i popieraniem innowacyjności gospodarki ${ }^{47}$.

\section{ZAKOŃCZENIE}

Wskazane zostało wiele celów, które może realizować prawo antymonopolowe. Ustalenia te mają charakter teoretyczny. To, jakie cele w praktyce realizowane są $\mathrm{w}$ danym systemie prawnym, zależy od wyboru ustawodawcy i analizy odnośnego ustawodawstwa. Należy podkreślić, że nie jest możliwe, aby wszystkie wyżej wskazane cele były realizowane jednocześnie. Niektóre $\mathrm{z}$ nich mają charakter konkurencyjny w stosunku do siebie, np. dobrobyt konsumencki i dobrobyt społeczny, inne zaś mogą mieć charakter wzajemnie wykluczający, jeśli nie w każdym przypadku, to przynajmniej w niektórych. Taka sytuacja najczęściej zachodzi w przypadku próby jednoczesnego realizowania celów politycznych i celów gospodarczych. Do pewnego stopnia cały czas tak było i jest w prawie unijnym, gdzie podkreśla się, że dwa podstawowe cele, którym ma ono służyć, tj. dobrobyt konsumencki oraz integracja rynku wewnętrznego, mogą w niektórych sytuacjach prowadzić do sprzeczności ${ }^{48}$.

Mówiąc o ekonomicznie uzasadnionych celach prawa konkurencji, należy także pamiętać, że celem prawa konkurencji nie jest wbrew powszechnemu mniemaniu ochrona konkurencji, a co najwyżej ochrona taka może być uznana za cel pośredni lub środek do osiągnięcia celu ostatecznego. Konkurencję należy bowiem traktować jako mechanizm efektywnej alokacji środków produkcji. Jednakże dzięki zagwarantowaniu efektywności tego mechanizmu możliwe jest osiągnięcie celu ostatecznego, jakim jest dobrobyt społeczny lub konsumencki (w zależności wyznawanego poglądu ekonomicznego). Oprócz tego celu ostatecznego ustawodawcy często próbują realizować pozagospodarcze cele, które w niewielkim stopniu mają swoje osadzenie ekonomii normatywnej, a raczej poglądach politycznych ustawodawcy.

${ }^{47}$ M. Błachucki, System postępowania antymonopolowego w sprawach kontroli koncentracji przedsiębiorców, UOKiK, Warszawa 2012, s. 303 i n.

${ }^{48}$ S. Bishop, M. Walker, op. cit., s. 5 i 6. 


\section{BIBLIOGRAFIA}

Amato G., Antitrust and the bounds of power. The dilemma of liberal democracy in the bistory of the market, Hart, Oxford 1997.

Baumol W.J., Panzer J.C, Willig R.D., Contestable Markets and the Theory of Industry Structure. Revised Edition, Hartcourt Brace Jovanovich, San Diego-Toronto 1988.

Bellamy \& Child, European Community law of competition, Oxford University Press, Oxford 2008.

Van den Bergh R., Camesasca P., European Competition Law and Economics. A Comparative Perspective, Sweet\&Maxwell, London 2006.

Bishop S., Walker M., The Economics of EC Competition Law: Concepts, Application and Measurement, Sweet \& Maxwell, London 2002.

Błachucki M., System postepowania antymonopolowego w sprawach kontroli koncentracji przedsiębiorców, UOKiK, Warszawa 2012.

Brito D., Catalao-Lopes M., Mergers and Acquisitions: The Industrial Organization Perspective, Kluwer Law International, The Hague 2006.

Decker Ch., Economics and the enforcement of European competition law, Edward Elgar, Cheltenham 2009.

Gerber D.J., Law and Competition in the Twentieth Century Europe. Protecting Prometheus, Oxford University Press, Oxford 2001.

Gronowski S., Polskie prawo antymonopolowe (zarys wyktadu), Wydawnictwo ZPP, Warszawa 1998.

Jurczyk Z., Cele polityki antymonopolowej w teorii i praktyce, [w:] C. Banasiński, E Stawicki (red.), Konkurencja w gospodarce wspótczesnej, UOKiK, Warszawa 2007.

Kirkwood J.B., Lande R.H., The Fundamental Goal of Antitrust: Protecting Consumers, Not Increasing Efficiency, http://ssrn.com/abstract=1113927 (08.03.13).

Kroes N., Consumers at the heart of EU Competition Policy, http://europa.eu/rapid/ pressReleasesAction.do? reference $=$ SPEECH/08/212\&format $=$ HTML\&aged $=0$ \&language $=\mathrm{EN} \&$ guiLanguage $=\mathrm{en}$ (08.03.13).

Lafargue P., Trusty amerykańskie. Ich dziatalność ekonomiczna, spoteczna i polityczna, Nakładem Wincentego Raabego, Warszawa 1907.

Miasik D., Controlled Chaos with Consumer Welfare as the Winner - a Study of the Goals of Polish Antirust Law, „Yearbook of Antitrust and Regulatory Studies” 2008, vol. 1(1).

Miąsik D., Reguta rozsądku w prawie antymonopolowym. Studium prawnoporórwnawcze, Zakamycze, Kraków 2004.

Miąsik D., Prawo konkurencji, [w:] R. Skubisz, E. Skrzydło-Tefelska (red.), Prawo europejskie. Zarys wyktadu, UMCS, Lublin 2004.

Motta M., Competition Policy. Theory and Practice, Cambridge University Press, Cambridge 2007.

Pace L., European Antitrust Law, Edward Elgar Publishing, Cheltenham - Northampton 2007. 
Phlips L., Competition policy: a game-theoretic perspective, Cambridge University Press, Cambridge 1995.

Rodriguez A.E., Menon A., The limits o competition policy, Wolters Kluwer, Hague, 2010.

Sauter W., Competition law and industrial Policy in the EU, Clarendon Press, Oxford 2003.

Shughart II W.F., Antitrust policy and interest-group politics, Quorum Books, New York-Westport-Connecticut-London 1990.

Skoczny T., Wprowadzenie, [w:] Prawo konkurencji, C.H. Beck, Warszawa 1995.

Waterson M., Economic theory of the industry, Cambridge University Press, Cambridge 1988.

Whish R., Competition Law, Oxford University Press, Oxford, 2009.

Zaech R., Competition law should promote economic and social welfare by ensuring the freedom to compete - a lawyer's view, [w:] J. Drexl, L. Idot, J. Moneger (red.), Economic Theory and Competition Law, Edward Elgar, Cheltenham-Northampton 2009.

Ziembiński Z., Wstęp do aksjologii dla prawnikórw, Wydawnictwo Prawnicze, Warszawa 1990. 
